J. Appl. Glycosci., 57, 193-197 (2010)

(C) 2010 The Japanese Society of Applied Glycoscience

Regular Paper

\title{
Improved Thermal Property and Absorption of Coenzyme Q10 in Humans Using Cyclodextrin
}

(Received October 21, 2009; Accepted March 18, 2010)

\author{
Hideki Takahashi, ${ }^{1, *}$ Yuri Bungo, ${ }^{1}$ Katsuhiko Mikuni, ${ }^{1}$ Hidehiko Beppu, ${ }^{2}$ Sayaka Ozaki, ${ }^{2}$ Kan Shimpo, \\ Yoshinori Itani $^{3}$ and Shigeru Sonoda ${ }^{2}$ \\ 'Carbohydrate Research Laboratory, Ensuiko Sugar Refining Co., Ltd. \\ (1-1-1, Fukuura, Kanazawa-ku, Yokohama 236-0004, Japan) \\ ${ }^{2}$ Fujita Memorial Nanakuri Institute, Fujita Health University (1865, Hisai-Isshiki-cho, Tsu 514-1296, Japan) \\ ${ }^{3}$ Nanakuri Sanatorium Hospital, Fujita Health University (424-1, Odori-cho, Tsu 514-1295, Japan)
}

\begin{abstract}
Coenzyme Q10 (CoQ10) is a well-known antioxidant agent that has low solubility in water and poor absorption in humans. CoQ10-cyclodextrin (CD) complex powders containing 20-24\% (w/w) CoQ10 were prepared to investigate the effects of different CDs on three properties of CoQ10: aqueous solubility, heat of fusion, and absorption in humans. The aqueous solubility of CoQ10 was increased by $\alpha-C D$ and dextrin, while $\beta$-CD, $\gamma$-CD and $\beta$-Iso ${ }^{\mathbb{R}}$ formed an insoluble complex with CoQ10. $\beta$-CD, $\gamma$-CD and $\beta$-Iso ${ }^{\mathbb{R}}$ improved the thermal property of CoQ10, as determined by differential scanning calorimetry. That is, $\beta$-CD, $\gamma$-CD and $\beta$-Iso ${ }^{\circledR}$ most likely formed complexes with CoQ10, as the CoQ10 endothermic peak obtained by differential scanning calorimetry greatly decreased in the presence of these compounds. For the absorption studies, 20 healthy female volunteers were divided randomly into four groups and orally administered either CoQ10, the CoQ10- $\beta$-CD complex, CoQ10- $\gamma$-CD complex or CoQ10- $\beta$-Iso ${ }^{\mathbb{R}}$ complex containing $0.30 \mathrm{~g}$ CoQ10 under fasting conditions. The concentration of CoQ10 in plasma before and 2, 4, 6, 8 and $24 \mathrm{~h}$ after sample administration was measured by HPLC analysis, and the plasma concentration of exogenous CoQ10 was calculated as the plasma concentration of $\mathrm{CoQ10}$ before administration subtracted from the value after administration. The area under the plasma exogenous CoQ10 concentration/time-course curve from 0 to $8 \mathrm{~h}$ of the three complex groups was significantly higher than that of the CoQ10 group, indicating that $\beta-\mathrm{CD}, \gamma-\mathrm{CD}$ and $\beta$-Iso ${ }^{\mathbb{R}}$ accelerate the absorption of CoQ10 in humans.
\end{abstract}

Key words: cyclodextrin, coenzyme Q10, complex, absorption

Coenzyme Q10 (ubiquinone-10, ubidecarenone ) (CoQ10) plays a role in energy production as a component of the mitochondrial electron transport system, and is used in pharmaceuticals, nutritional supplements and cosmetics because of its antioxidant function. Although CoQ10 has low water solubility and is poorly absorbed by the body, the absorption of CoQ10 from products is enhanced by emulsifiers. ${ }^{1)}$ Many studies regarding the absorption of CoQ10 in humans have been reported, ${ }^{2-7)}$ and the physico-chemical properties of CoQ10 have been studied. Lutka et al. evaluated the solubility of CoQ10 in water containing cyclodextrins (CDs), and the formation of inclusion complexes between CoQ10 and CDs has been studied using IR spectrometry, x-ray diffractometry and differential scanning calorimetry (DSC). ${ }^{8,9)}$ Terao et al. compared the absorption of CoQ10 in healthy adult volunteers who were administered CoQ10 either as a CoQ10- $\gamma$-CD complex or a mixture of CoQ10 and microcrystalline cellulose. ${ }^{10)}$ The present study investigated the effect of $\mathrm{CD}$ on the water solubility and thermal property (using DSC) of CoQ10, as well as its absorption in humans when administered as a complex with different CDs.

* Corresponding author (Tel.+81-45-780-1922, Fax.+81-45-7801920, E-mail: htakahashi@ensuiko.co.jp)

\section{MATERIALS AND METHODS}

Materials. CoQ10 for the preparation of complexes with CDs was purchased from Tradepia Corp. (Tokyo, Japan) Sandec \#250 (DE 22-26\%; Sanwa Cornstarch Co., Ltd., Nara, Japan) was used as a dextrin. $\alpha-C D, \beta-C D, \gamma-$ $\mathrm{CD}$ and $\beta$-Iso ${ }^{\circledR}$ were supplied by Ensuiko Sugar Refining Co., Ltd. (Tokyo, Japan) $\beta$-Iso ${ }^{\circledR}$ consisted of $3 \%$ maltose, $1 \%$ maltosyl maltose, $4 \% \alpha-\mathrm{CD}, 76 \% \beta-\mathrm{CD}, 2 \% \quad \gamma-\mathrm{CD}$, $6 \%$ 6- $O$ - $\alpha$-maltosyl- $\alpha-\mathrm{CD}, 2 \%$ 6- $O$ - $\alpha$-maltosyl- $\beta-\mathrm{CD}, 3 \%$ $6-O-\alpha$-maltosyl- $\gamma-\mathrm{CD}+6,6^{\prime}$-di- $O-\alpha$-maltosyl- $\alpha-\mathrm{CD}, 2 \%$ $6,6^{\prime}$-di- $O-\alpha$-maltosyl- $\beta-\mathrm{CD}$ and $1 \% \quad 6,6^{\prime}$-di- $O$ - $\alpha$-maltosyl$\gamma$-CD (w/w). 2-Propanol and methanol were purchased from Nacalai Tesque, Inc. (Kyoto, Japan). Sodium perchlorate was obtained from Sigma-Aldrich Co. (St. Louis, USA). Water purified by a Milli-Q Ultrapure Water Purification System (Millipore Co., Billerica, USA) was used for HPLC. All other chemicals used were of analytical grade.

Preparation of the CoQ10-dextrin and CoQ10-CD complexes. CoQ10 (100 g) was added to solutions of dextrin, $\alpha-\mathrm{CD}, \beta-\mathrm{CD}, \gamma-\mathrm{CD}$ and $\beta$-Iso ${ }^{\circledR}$ (each $400 \mathrm{~g}$ ), which were dissolved in $2 \mathrm{~L}$ water at $70^{\circ} \mathrm{C}$. After the CoQ10 melted, the two-layer sample was homogenized at $8000 \mathrm{rpm}$ for $15 \mathrm{~min}$ at $70^{\circ} \mathrm{C}$, and then further homogenized at $8000 \mathrm{rpm}$ for $15 \mathrm{~min}$ using a water jacket to cool 
the sample to $40^{\circ} \mathrm{C}$. The emulsion was treated at $10 \mathrm{MPa}$ with a high-pressure homogenizer (NS2006H, Niro Soavi Co., Hudson, USA) and was powdered using a conventional spray-dry method. The CoQ10 content in the prepared complexes was measured. The loss on drying of the $1 \mathrm{~g}$ complex was estimated by measuring the mass before and after heating at $80^{\circ} \mathrm{C}$ for $18 \mathrm{~h}$ below $0.67 \mathrm{MPa}$. Ten milligrams of the complex was dissolved at $70^{\circ} \mathrm{C}$ after 5 $\mathrm{mL}$ dimethylsulfoxide was added. The solution was adjusted to $10 \mathrm{~mL}$ with 2-propanol after cooling until room temperature and was filtered through a $0.2 \mu \mathrm{m}$ membrane filter. The $20 \mu \mathrm{L}$ filtrate was injected on an HPLC column. HPLC analysis was carried out under the conditions described in the solubility study section. Ethanol solutions containing $100-400 \mu \mathrm{g} / \mathrm{mL}$ CoQ10 as an external standard were also injected. The CoQ10 content in the complex as a solid weight was determined. The CoQ10 content of the CoQ10-dextrin, CoQ10- $\alpha-C D$, CoQ10- $\beta-C D$, CoQ10- $\gamma$-CD and CoQ10- $\beta$-Iso ${ }^{\circledR}$ complexes were 20,20 , 21, 21 and $24 \%(\mathrm{w} / \mathrm{w})$, respectively.

Solubility study. The CoQ10-dextrin complex or the CoQ10-CD complexes equivalent to $1 \mathrm{~g}$ and $5 \mathrm{~g}$ dextrin or $\mathrm{CD}$ were added in water, and the mixtures were stirred and adjusted to $100 \mathrm{~mL}$ with water. The suspensions were homogenized at $6000 \mathrm{rpm}$ for $1 \mathrm{~h}$ at $37^{\circ} \mathrm{C}$. Each suspension was filtered through a $0.2 \mu \mathrm{m}$ membrane filter, and $20 \mu \mathrm{L}$ filtrate was injected into an HPLC column for analysis of the solubility of CoQ10 in the complexes. The HPLC system consisted of a LC-20AD pump (Shimadzu Co., Kyoto, Japan), UV-8011 UV detector (Tosoh Co., Tokyo, Japan) and C-R7A data processor (Shimadzu Co.). The following conditions were used: column, Wakosil-II 5 C18RS (150 × 4.6 mm I.D.) (Wako Pure Chemical Industry, Ltd., Osaka, Japan); column temperature, $35^{\circ} \mathrm{C}$; mobile phase, $N, N$-dimethylformamide; flow rate, $1.0 \mathrm{~mL} /$ min; detection wavelength, $275 \mathrm{~nm}$.

DSC analysis. Samples containing $1 \mathrm{mg}$ CoQ10 were analyzed by DSC from ambient temperature to $100^{\circ} \mathrm{C}$ under a stream of nitrogen $(30 \mathrm{~mL} / \mathrm{min})$ at a scan rate of $2^{\circ} \mathrm{C} / \mathrm{min}$ on a DSC-50 (Shimadzu Co.).

Absorption study. Twenty healthy female volunteers (age $38.9 \pm 4.5$ years) participated in this study. Each subject provided written informed consent before participating in the study, in accordance with the Helsinki II Declaration. The study was approved by the Ethics Committee of Fujita Health University and was carried out under the supervision of a doctor. The subjects were divided into four groups of five participants each. Each group was administered either CoQ10, the CoQ10- $\beta-C D$ complex,

Table 1. Mean weight of subjects and doses administered to each group.

\begin{tabular}{lccc}
\hline \multicolumn{1}{c}{ Administration } & $\begin{array}{c}\text { Mean weight } \\
\text { of subject } \\
(\mathrm{kg})\end{array}$ & $\begin{array}{c}\text { CoQ10 } \\
\text { content } \\
\text { in sample } \\
(\%)\end{array}$ & $\begin{array}{c}\text { Adminis- } \\
\text { tered } \\
\text { dose } \\
(\mathrm{g})\end{array}$ \\
\hline CoQ10 & $53.1 \pm 6.7$ & 100 & 0.30 \\
CoQ10- $\gamma$-CD complex & $54.1 \pm 6.1$ & 21 & 1.43 \\
CoQ10- $\beta$-CD complex & $52.5 \pm 4.3$ & 21 & 1.43 \\
CoQ10- $\beta$-Iso ${ }^{\circledR}$ complex & $52.2 \pm 9.7$ & 24 & 1.25 \\
\hline
\end{tabular}

Weight is expressed as the mean $\pm \mathrm{SD}, n=5$.
CoQ10- $\gamma$-CD complex or CoQ10- $\beta$-Iso ${ }^{\circledR}$ complex. The subjects fasted for $12 \mathrm{~h}$ before administration. Each sample contained $0.30 \mathrm{~g}$ CoQ10 and was administrated with $200 \mathrm{~mL}$ water (at 09:00). The mean weight of each group and the amount of sample administered is shown in Table 1. Between 2 and $4 \mathrm{~h}$ after administration, each subject had a meal consisting of two rice balls, pickles, vegetable salad, fruit and Japanese tea.

Venous blood was collected before and 2, 4, 6, 8 and $24 \mathrm{~h}$ after sample administration using heparinized syringes. Samples were immediately centrifuged at $3000 \mathrm{rpm}$ for $15 \mathrm{~min}$ and the plasma was frozen at $-84^{\circ} \mathrm{C}$ until analysis.

Safety assessments including physical examinations (body mass, body mass index (BMI), blood pressure and vital signs), clinical chemistry (total protein (TP), total cholesterol (T-chol), HDL cholesterol (HDL-chol), albumin (ALB), total bilirubin (T-bil), indirect bilirubin (I-bil), glucose, triglycerol (TG), blood urea nitrogen (BUN), creatinine, uric acid (UA), $\mathrm{Na}, \mathrm{Cl}, \mathrm{K}, \mathrm{Ca}, \mathrm{Fe}$, glutamyl oxaloacetic transaminase, glutamyl pyruvic transaminase, lactate dehydrogenase (LDH), alkaline phosphatase (ALP) and $\gamma$-glutamyl transpeptidase $(\gamma$-GTP)), hematological tests (white blood cell, red blood cell (RBC), hemoglobin, hematocrit $(\mathrm{Ht})$, mean corpuscular volume (MCV), mean corpuscular hemoglobin, mean corpuscular hemoglobin concentration and platelets) and urine analyses $(\mathrm{pH}$, specific gravity, protein, glucose, urobilinogen, bilirubin, ketone body, blood and white blood cell) were performed. Physical examinations and urine analyses were conducted within $26 \mathrm{~h}$ before and after administration of the CoQ10 sample. Clinical chemistry and hematological tests were conducted on the plasma samples collected before and $24 \mathrm{~h}$ after sample administration.

Frozen plasma samples were thawed at room temperature in the dark just prior to analysis. Plasma $(20 \mu \mathrm{L})$ was mixed with $100 \mu \mathrm{L}$ 2-propanol, followed by an additional $100 \mu \mathrm{L}$ 2-propanol and then mixed. The resultant mixtures were centrifuged at $1200 \mathrm{rpm}$ at $4{ }^{\circ} \mathrm{C}$ for $5 \mathrm{~min}$ and $20 \mu \mathrm{L}$ of each supernatant was then injected and analyzed by HPLC. ${ }^{10)}$ A NANOSPACE SI-2 CoQ10 system (Shiseido Co., Ltd., Tokyo, Japan) was used as the HPLC system. It was composed of an auto sampler, two valves, two pumps, a concentration column of CoQ10 in sample (CAPCELL PAK C18 AQ S5, $35 \times 2.0$ mm I.D., $5 \mu \mathrm{m}$, Shiseido Co.), a reduction column to convert CoQ10 to ubiquinol-10 (CAPCELL PAK CQ, $20 \times 2.0 \mathrm{~mm}$ I.D., Shiseido Co.), an analytical column (CAPCELL PAK C18 AQ S5, $150 \times 2.0 \mathrm{~mm}$ I.D., $3 \mu \mathrm{m}$, Shiseido Co.), a column oven (controlled at $40^{\circ} \mathrm{C}$ ), an electrochemical detector $(600 \mathrm{mV}, \mathrm{Ag} / \mathrm{AgCl})$, and an integrator. A twenty $\mu \mathrm{L}$ sample was injected into the concentration column with $50 \mathrm{mM}$ sodium perchlorate in methanol/water $(19: 1, \mathrm{v} / \mathrm{v})$ as a mobile phase at a flow rate of $0.2 \mathrm{~mL} / \mathrm{min}$ for 2 minutes and the CoQ10 in the sample was absorbed in the concentration column. The flow of the concentration column was automatically switched from a drain to the reduction column and the following analytical column using two valves and the mobile phase of $50 \mathrm{~mm}$ sodium perchlorate in methanol/2-propanol $(19: 1, \mathrm{v} / \mathrm{v})$ was passed at a flow rate of $0.4 \mathrm{~mL} / \mathrm{min}$ for $11 \mathrm{~min}$. Ubiquinol-10 
eluted from the analytical column was detected by the electrochemical detector. The concentration of CoQ10 in plasma was determined as the total amount of ubiquinol10 (the reduced form of CoQ10) because CoQ10 also exists as ubiquinol-10 in plasma.

Each analyte concentration was expressed as the mean \pm the standard deviation (SD). For physical examinations, clinical chemistry, hematological tests and urine analyses, the paired $t$-test was used to analyze differences before and after the absorption study. The maximum plasma concentration $\left(C_{\max }\right)$, time to reach maximum plasma concentration $\left(T_{\max }\right)$ and the area under the plasma concentration/time-course curve from 0 to $8 \mathrm{~h}$ (AUC $0-$ $8 \mathrm{~h}$ ) were obtained directly from the plasma concentration/time-course data. AUC was calculated by the linear trapezoidal rule where the area of the trapezoid corresponds to all values of the CoQ10 plasma concentrations between measurements added together. The plasma concentration of exogenous CoQ10 was calculated as the plasma concentration of CoQ10 before administration subtracted from the value after administration.

The significance of differences in the plasma CoQ10 concentration between the CoQ10 alone and CoQ10-CD complex groups was analyzed by a non-parametric method (Mann-Whitney U-test). A $p$-value $<0.05$ was regarded as significant.

\section{RESULTS AND DISCUSSION}

\section{Solubility of the CoQ10-dextrin and CoQ10-CD com- plexes.}

The physical state of the suspensions was observed when the dextrin or CD solution was homogenized with melted CoQ10 to prepare the CoQ10-dextrin or CoQ10CD complex. $\beta-\mathrm{CD}, \gamma-\mathrm{CD}$ and $\beta$-Iso ${ }^{\circledR}$ formed emulsions, while dextrin and $\alpha-C D$ each formed a layer with the melted CoQ10 that separated from the water layer. The $4: 1(\mathrm{w} / \mathrm{w})$ ratio of dextrin or $\alpha-\mathrm{CD}$ to $\mathrm{CoQ} 10$, which is equivalent to a 3.6:1 molar ratio of $\alpha-\mathrm{CD}$ (MW: 973) to CoQ10 (MW: 863), appeared to be an excess of CoQ10 because emulsification of melted CoQ10 was not perfectly achieved with dextrin or $\alpha-C D$ solution and melted CoQ10 remained as an oil phase.

Figure 1 shows the aqueous solubility of CoQ10 in the CoQ10-dextrin and CoQ10-CD complexes. Both the CoQ10- $\alpha-C D$ and CoQ10-dextrin complexes enhanced the

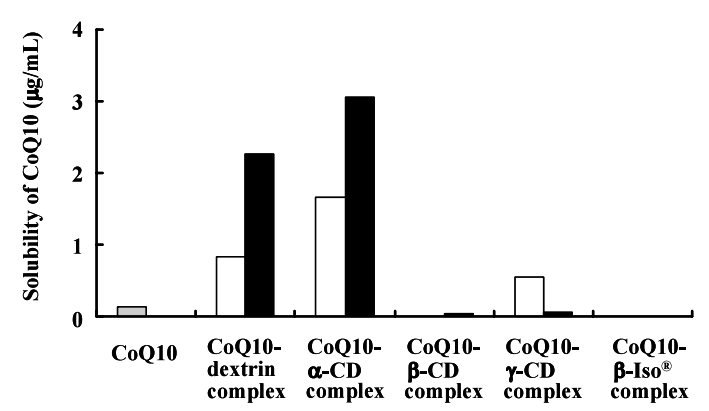

Fig. 1. Aqueous solubility of CoQ10 in the CoQ10-dextrin and CoQ10-CD complexes.

An aqueous suspension of complex corresponding to $1 \%(\mathrm{w} / \mathrm{v})$ (white bars) or $5 \%(\mathrm{w} / \mathrm{v})$ (black bars) dextrin or CD was homogenized at $6000 \mathrm{rpm}$ for $1 \mathrm{~h}$ at $37^{\circ} \mathrm{C}$. solubility of CoQ10 relative to its concentration in the aqueous suspension. The CoQ10- $\gamma$-CD aqueous suspension with $1 \%(\mathrm{w} / \mathrm{v}) \gamma-\mathrm{CD}$ improved the solubility of CoQ10, but increasing the concentration of $\gamma$-CD to $5 \%$ $(\mathrm{w} / \mathrm{v})$ did not further improve the solubility of CoQ10. CoQ10 in the CoQ10- $\beta-C D$ and CoQ10- $\beta$-Iso ${ }^{\circledR}$ complexes was sparingly soluble in water. $\beta-\mathrm{CD}, \gamma-\mathrm{CD}(5 \%)$ and $\beta$-Iso ${ }^{\circledR}$ seemed to form an insoluble complex with CoQ10. The results of CoQ10 when complexed with $\gamma$-CD showed lower aqueous solubility than that reported by Lutka et $a l .^{8,9)}$

\section{DSC analysis.}

Figure 2 shows the DSC thermograms of CoQ10 and the CoQ10-dextrin and CoQ10-CD complexes, where each sample corresponded to $1 \mathrm{mg}$ CoQ10. The endothermic peaks, caused by the heat of fusion of CoQ10, for the CoQ10- $\gamma$-CD and CoQ10- $\beta$-Iso ${ }^{\circledR}$ complexes were very small, while the peak for the CoQ10- $\beta-C D$ complex was slightly larger. In contrast, the size of the endothermic peaks for the CoQ10-dextrin and CoQ10- $\alpha$-CD complexes were similar to that for CoQ10. These results suggested that $\gamma-C D$ and $\beta-C D$ were suitable for forming complexes with CoQ10, even though these CDs did not increase the aqueous solubility of CoQ10. In contrast, dextrin and $\alpha-C D$ did not appear to form a complex with CoQ10, even though they increased the solubility of CoQ10. Thus, many intact CoQ10 molecules might exist in the CoQ10dextrin and CoQ10- $\alpha-C D$ complexes.

\section{Absorption of CoQ10 from orally administered CoQ10 complexes.}

The samples for the absorption study were selected. Emulsification of melted CoQ10 with the dextrin or $\alpha-C D$ solution was not observed when the CoQ10-dextrin and CoQ10-CD complexes were prepared. In addition, the CoQ10-dextrin and CoQ10- $\alpha-C D$ complexes had almost the same size of endothermic peak as CoQ10.

CoQ10 and the CoQ10- $\beta-C D$, CoQ10- $\gamma-C D$ and CoQ10- $\beta$-Iso ${ }^{\circledR}$ complexes were orally administered to four groups of fasted subjects, who all showed normal results for physical examinations, clinical chemistry, hematological tests and urine analyses; however, after administration the values of TP, T-chol, HDL-chol, ALB, T-bil, I-bil,

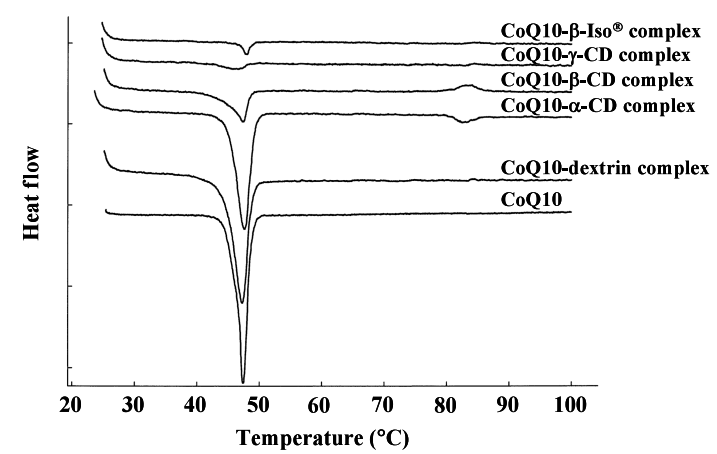

Fig. 2. DSC thermograms of CoQ10 and the CoQ10-dextrin and CoQ10-CD complexes.

Sample sizes were equivalent to $1 \mathrm{mg}$ CoQ10. Temperature: ambient to $100^{\circ} \mathrm{C}, 2^{\circ} \mathrm{C} / \mathrm{min}$. Samples were maintained under a stream of nitrogen. 
BUN, UA, Fe, ALP, $\gamma$-GTP, RBC, Ht and MCV were significantly reduced, while the those of $\mathrm{TG}, \mathrm{Na}, \mathrm{Cl}$ and $\mathrm{K}$ were significantly increased. The CoQ10 complexes did not appear to affect the health of the subjects. No subjects complained of any unusual physical condition.

The mean plasma concentration of CoQ10 in subjects before administration was $616 \pm 145.2 \mathrm{ng} / \mathrm{mL}$ in the CoQ10 group, $438 \pm 212.5 \mathrm{ng} / \mathrm{mL}$ in the CoQ10- $\beta-\mathrm{CD}$ complex group, $608 \pm 159.9 \mathrm{ng} / \mathrm{mL}$ in the CoQ10- $\gamma-\mathrm{CD}$ complex group and $640 \pm 142.4 \mathrm{ng} / \mathrm{mL}$ in the CoQ10- $\beta$ Iso ${ }^{\circledR}$ complex group. Although the concentration in the CoQ10- $\beta$-CD complex group was lower than those in the

Table 2. Pharmacokinetic parameters of CoQ10 after oral administration of $0.30 \mathrm{~g} \mathrm{CoQ} 10$ or the CoQ10-CD complexes containing $0.30 \mathrm{~g} \mathrm{CoQ} 10$.

\begin{tabular}{lccc}
\hline \multicolumn{1}{c}{ Administration } & $\begin{array}{c}T_{\max } \\
(\mathrm{h})\end{array}$ & $\begin{array}{c}C_{\max } \\
(\mathrm{ng} / \mathrm{mL})\end{array}$ & $\begin{array}{c}\text { AUC 0-8 h } \\
(\mathrm{ng} \times \mathrm{h} / \mathrm{mL})\end{array}$ \\
\hline CoQ10 & $3.8 \pm 3.3$ & $635 \pm 145$ & $4823 \pm 1166$ \\
CoQ10- $\gamma$-CD complex & $5.6 \pm 1.7$ & $1094 \pm 449^{*}$ & $6938 \pm 2752$ \\
CoQ10- $\beta$-CD complex & $6.0 \pm 1.4$ & $769 \pm 150$ & $4706 \pm 1327$ \\
CoQ10- $\beta-$-Iso ${ }^{\circledR}$ complex & $4.8 \pm 1.1$ & $1069 \pm 323^{*}$ & $6766 \pm 1986$ \\
\hline
\end{tabular}

Each result is expressed as the mean $\pm \mathrm{SD}, n=5$. The significant differences between the CoQ10-administered group and the CoQ10-CD complex-administered group were compared. ${ }^{*} p<0.05$. $T_{\max }$, time to reach maximum plasma concentration; $C_{\max }$, maximum plasma concentration; AUC 0-8 h, area under the plasma concentration/time-course curve from 0 to $8 \mathrm{~h}$.

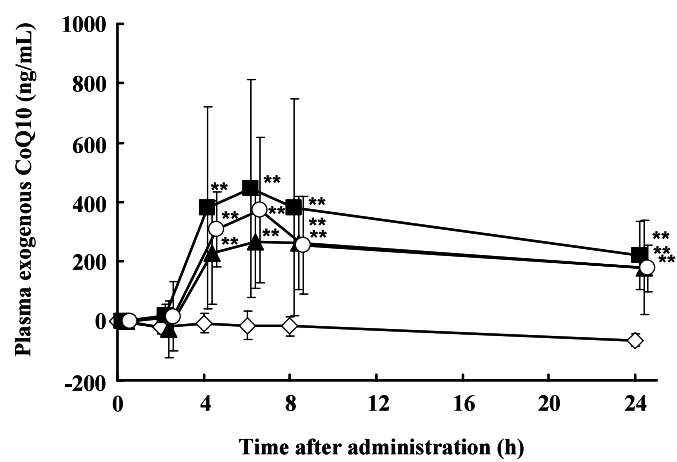

Fig. 3. Time-course of mean plasma concentration of exogenous CoQ10 after oral administration of $0.30 \mathrm{~g} \mathrm{CoQ10}$ and three CoQ10-CD complexes containing 0.30 g CoQ10.

, CoQ10- $\gamma$-CD complex group; $\bigcirc$, CoQ10- $\beta-$ Iso $^{\circledR}$ complex group; $\mathbf{\Delta}$, CoQ10- $\beta-\mathrm{CD}$ complex group; $\diamond$, CoQ10 group. Each point represents the mean $\pm \mathrm{SD}, n=5 .{ }^{* *} p<0.01$, compared with the CoQ10 group at each time point after administration.

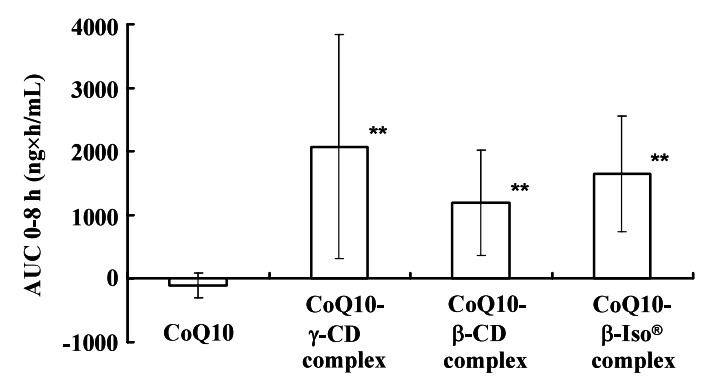

Fig. 4. AUC 0-8 h calculated from the time-course of the plasma concentration of exogenous CoQ10 following oral administration of $0.30 \mathrm{~g}$ CoQ10, or the CoQ10-CD complexes containing $0.30 \mathrm{~g} \mathrm{CoQ} 10$.

Each value represents the mean $\pm \mathrm{SD}, n=5$. The significant differences between the CoQ10 group and the CoQ10-CD complex groups were compared. ${ }^{* *} p<0.01$. other three groups, the difference was not significant.

The pharmacokinetic parameters calculated for all four treatments are presented in Table 2. $C_{\max }$ of the CoQ10- $\gamma$ $\mathrm{CD}$ and CoQ10- $\beta$-Iso ${ }^{\circledR}$ complex groups were significantly higher $(p<0.05)$ than that of the CoQ10 group. AUC 0$8 \mathrm{~h}$ of the CoQ10- $\gamma-\mathrm{CD}$ and CoQ10- $\beta$-Iso ${ }^{\circledR}$ complex groups was 1.4 times larger than that of the CoQ10 group, but the differences were not statistically significant. This result may reflect the higher plasma concentration of endogenous CoQ10 compared to exogenous CoQ10. AUC $0-8 \mathrm{~h}$ of the CoQ10- $\beta-\mathrm{CD}$ complex group was almost the same as that of the CoQ10 group, because the plasma concentration of CoQ10 in the CoQ10- $\beta-C D$ complex group prior to administration was lower than that of the other three groups.

The time-course of the plasma concentration of exogenous CoQ10 is shown in Fig. 3. The concentration of CoQ10 at 4, 6, 8 and $24 \mathrm{~h}$ after administration of the three CoQ10-CD complexes was consistently and significantly higher $(p<0.01)$ than that following administration of CoQ10 alone. The plasma CoQ10 concentration reached a maximum $6 \mathrm{~h}$ after administration and then gradually decreased in all the CoQ10-CD groups, while that in the CoQ10 group showed no increase during the time-course.

Figure 4 shows AUC 0-8 h calculated from the timecourse of the plasma concentration of exogenous CoQ10 from Fig. 3. The AUC values from the CoQ10- $\gamma-C D$, CoQ10- $\beta$-Iso ${ }^{\circledR}$ and CoQ10- $\beta-C D$ complex groups were significantly higher $(p<0.01)$ than that from the CoQ10 group. These values followed the order: CoQ10- $\gamma-\mathrm{CD}$ group $>$ CoQ $10-\beta$-Iso ${ }^{\circledR}$ group $>$ CoQ $10-\beta-C D$ group . Since $\beta$-Iso ${ }^{\circledR}$ contains $76 \% \beta$-CD and $14 \%$ maltosyl CDs, the maltosyl CDs in $\beta$-Iso ${ }^{\circledR}$ might strongly affect the absorption of CoQ10.

Terao et al. reported that the oral administration of the CoQ10- $\gamma-C D$ complex to healthy adult volunteers enhanced absorption of CoQ10 compared with a mixture of CoQ10 and microcrystalline cellulose. ${ }^{10)}$ Our results of the DSC analysis suggest that CoQ10- $\gamma-C D$ and the CoQ10$\beta$-Iso ${ }^{\circledR}$ and CoQ10- $\beta$-CD complexes mainly formed complexes between $\mathrm{CD}$ and CoQ10, resulting in higher absorption of CoQ10 in humans than intact CoQ10 alone. It appears that the absorption of CoQ10 was increased because of the increased dispersiveness of CoQ10 after complexing with $\gamma$-CD, $\beta$-Iso ${ }^{\circledR}$ and $\beta$-CD. It is therefore expected that CDs can be used to increase the bioavailability of CoQ10 in humans.

\section{CONCLUSION}

$\alpha-C D$ and dextrin increased the aqueous solubility of CoQ10, but it was indicated by DSC analysis that these did not form complexes with CoQ10. CoQ10 might have some interaction and form a small amount of soluble complex with $\alpha-C D$ and dextrin by homogenization in water. On the other hand, it was shown that $\beta-C D, \gamma-C D$ and $\beta$-Iso ${ }^{\circledR}$ formed complexes with CoQ10 though $\beta$-CD and $\beta$-Iso ${ }^{\circledR}$ didn't increase the solubility of CoQ10, whereas $\gamma-C D$ somewhat increased the solubility of CoQ10 under a lower concentration of its complex. These 
results suggested that $\beta-\mathrm{CD}, \gamma-\mathrm{CD}$ and $\beta$-Iso ${ }^{\circledR}$ formed mainly insoluble complexes with CoQ10. Moreover, DSC analysis of the CoQ10- $\beta-C D, C o Q 10-\gamma-C D$ and CoQ10- $\beta-$ Iso $^{\circledR}$ complexes supported that $\beta$-CD, $\gamma$-CD and $\beta$-Iso ${ }^{\circledR}$ formed complexes with CoQ10. The absorption of CoQ10 in humans was improved by the administration of the CoQ10- $\beta-\mathrm{CD}, \mathrm{CoQ} 10-\gamma-\mathrm{CD}$ and CoQ10- $\beta$-Iso ${ }^{\circledR}$ complexes in comparison with the administration of CoQ10 alone. It was inferred that $\beta$-CD, $\gamma$-CD and $\beta$-Iso ${ }^{\circledR}$ accelerated the absorption of CoQ10 because of the increased dispersiveness of CoQ10 after encapsulating CoQ10 molecules.

\section{REFERENCES}

1 ) M. Shimomura and Y. Miyamoto: Comparative bioavailability between "coenzyme Q10 emulsion powder" and "coenzyme Q10 in bulk" in humans. J. Nutr. Food, 9, 43-51 (2006).

2 ) Y. Tomono, J. Hasegawa, T. Seki, K. Motegi and N. Morishita: Pharmacokinetic study of deuterium-labelled coenzyme Q10 in man. Int. J. Clin. Pharmacol. Ther. Toxicol., 24, 536541 (1986).

3 ) C. Weber, T.S. Jakobsen, S.A. Mortensen, G. Paulsen and G. Holmer: Effect of dietary coenzyme Q10 as an antioxidant in human plasma. Mol. Aspects Med., 15, S97-S102 (1994).

4 ) C. Weber, A. Bysted and G. Holmer: Intestinal absorption of coenzyme Q10 administered in a meal or as capsules to healthy subjects. Nutr. Res., 17, 941-945 (1997).

5 ) J. Kaikkonen, K. Nyyssonen, T.-P. Tuomainen, U. Ristonmaa and J.T. Salonen: Determinants of plasma coenzyme Q10 in humans. FEBS Lett., 443, 163-166 (1999).

6 ) J. Kaikkonen, T.-P. Tuomainen, K. Nyyssonen and J.T. Salonen: Coenzyme Q10: absorption, antioxidative properties, determinants, and plasma levels. Free Radic. Res., 36, 389-397 (2002).

7 ) C. Zita, K. Overvad, S.A. Mortensen, C.D. Sindberg, S. Moesgaard and D.A. Hunter: Serum coenzyme Q10 concentrations in healthy men supplemented with $30 \mathrm{mg}$ or $100 \mathrm{mg}$ coenzyme Q10 for two months in a randomised controlled study. BioFactors, 18, 185-193 (2003).

8 ) A. Lutka and J. Pawlaczyk: Inclusion complexation of coenzyme Q10 with cyclodextrins. Acta Pol. Pharm., 52, 379-386 (1995).

9 ) A. Lutka and J. Pawlaczyk: Investigation of inclusion complexes of coenzyme Q10 with $\gamma$-cyclodextrin and methyl- $\beta$ cyclodextrin $(\mathrm{MS}=0.97)$. Part I. Comparison of complexation methods in the solution state. Acta Pol. Pharm., 53, 193-196 (1996).

10) K. Terao, D. Nakata, H. Fukumi, G. Schmid, H. Arima, F. Hirayama and K. Uekama: Enhancement of oral bioavailability of coenzyme Q10 by complexation with $\gamma$-cyclodextrin in healthy adults. Nutr. Res., 26, 503-508 (2006).

\section{サイクロデキストリンを用いたコエンザイム Q10 の 熱特性とヒトにおける吸収性の改善 \\ 高橋英樹'，文後有里'，三國克彦'，別府秀彦 尾崎清香 ${ }^{2}$, 新保 寛 ${ }^{2}$, 井谷功典 ${ }^{3}$, 園田 茂 ${ }^{2}$ \\ '塩水港精糖株式会社糖質研究所 \\ (236-0004 神奈川県横浜市金沢区福浦 1-1-1) \\ 2 藤田保健衛生大学藤田記念七栗研究所 \\ (514-1296 三重県津市久居一色町 1865) \\ 3 藤田保健衛生大学七栗サナトリウム \\ (514-1295 三重県津市大鳥町 424-1)}

サイクロデキストリン $(\mathrm{CD})$ がコエンザイム $\mathrm{Q} 10$ (CoQ10) の水への溶解性, 融解熱, ヒトにおける吸収性 に及ぼす影響を調べるため, CoQ10を20-24 重量\%含む CoQ10-CD 複合体粉末を調製した. CoQ10 の水溶性は, $\alpha-\mathrm{CD}$ ，デキストリンである程度の改善がみられた。一 方, 示差走查熱量計分析では, CoQ10の吸熱ピークが $\beta$ $\mathrm{CD}, \gamma$-CD, $\beta$-Iso ${ }^{\circledR}$ の存在でほぼ消失したことから， $\beta$ $\mathrm{CD}, \gamma$-CD, $\beta$-Iso ${ }^{\circledR}$ は, 粉末中の $\mathrm{CoQ} 10$ をほほ包接した不 溶性複合体を形成することが確認された。吸収試験では, 健康な成人女性 20 名を 4 群に分け, CoQ10 原末, CoQ10$\beta-\mathrm{CD}$ 複合体粉末, CoQ10- $\gamma-\mathrm{CD}$ 複合体粉末または CoQ10$\beta$-Iso ${ }^{\circledR}$ 複合体粉末の CoQ10 として $0.30 \mathrm{~g}$ 相当量が絶食下 で単回摂取され，摂取前 (0 時間) および摂取 $2,4,6$, 8， 24 時間後の血漿中総 CoQ10 濃度を HPLC で測定した。 $\mathrm{CoQ} 10$ 摂取後の血槳中総 $\mathrm{CoQ} 10$ 濃度から摂取前の濃度を 引いた血漿中外因性総 $\mathrm{CoQ} 10$ 濃度を求めて吸収性を評価 したとき，CoQ10- $\beta-C D$ 複合体摂取群，CoQ10- $\gamma-C D$ 複合 体摂取群，CoQ10- $\beta-$-Iso ${ }^{\circledR}$ 複合体摂取群の摂取 0-8 時間にお ける血漿中外因性総 CoQ10 濃度-時間曲線下面積は, $\mathrm{CoQ} 10$ 原末摂取群と比較して有意 $(p<0.01)$ な増加が認 められ， $\beta-\mathrm{CD}, \gamma$-CD, $\beta$-Iso ${ }^{\circledR}$ がヒトに㧍ける $\mathrm{CoQ} 10$ の吸 収を促進することが示された。 